\title{
Silent Competition among Students: How Schadenfreude and Social Envy Influence Rating-based Achievement Motivation
}

\author{
Bilson Simamora \\ Management Department, Kwik Kian Gie School of Business and Information Technology, \\ Jakarta 14350, Indonesia. \\ bilson.simamora@kwikkiangie.ac.id
}

\begin{abstract}
Schadenfreude and social envy have attracted human interest for thousands of years. However, little is know about how they influence achievement motivation in a hierarchical and competitive social environment. To overcome this problem, inspired by Mayer and Salovey's (1997) emotional intelligence theory, the author develops rivals' anticipated emotions (RAE) and models how the sense of being envied and become the schadenfreude target influence the motivation to avoid the decrease of or to increase current competitive position. The study follows Higgin's (1997) self-regulatory framework in students' context. In the schadenfreude scenario, as part of self-protection, the study proposes that the sense of being a schadenfreude target, represented by rivals' anticipated joyfulness (RAJ), influences students' motivation to avoid the decrease of current competitive position (prevention focus), especially for those who occupy upper and medium positions. Rivals' anticipated distress (RAD) that represents the sense of being envied stimulates students' motivation to increase competitive position (promotion focus), especially for those who occupy the lower and medium position. When working together, the RAJ and RAD stimulate promotion and avoidance motivations simultaneously, especially among mediocre students. Future researchers can widen their investigation into intergroup schadenfreude and social envy research domains.
\end{abstract}

Keywords: Social envy, schadenfreude, rivals' anticipated emotions, achievement motivation.

Received 6 October 2020/Accepted 6 March 202I @Author all rights reserved

\section{Introduction}

Social envy is resentment caused by the envied ownership of prestigious objects the enviers do not have. Conversely, schadenfreude is a feeling of joy over others' misfortune. Humanity has known them as dangerous behaviors for thousands of years ago. This view inspires most of the initial research in this field which has the negative affective states generated by these emotions as the primary focus (Aquaro, 2004; Lange et al., 2018; Lange \& Crusius, 2015).

Social envy naturally co-exists with schadenfreude (Cecconi et al., 2020; Piskorz \& Piskorz, 2009). However, the demarcation line between them is blurred (Graham \& Weiner, 1996; 
Hareli \& Weiner, 2002). Some researchers (Hareli \& Weiner, 2002; Smith \& van Dijk, 20I8) see social envy as the antecedent of schadenfreude. Van Dijk et al. (2006) agree that that notion, especially when the gender of the target, is similar to that of the observers. However, (van de Ven \& Zeelenberg, 2015) stated that it is only malicious envy, not benign envy, that influences schadenfreude. Conversely, according to Feather and Sherman (2002), it is resentment, not envy, the factor that determines schadenfreude. On the other hand, for Piskorz and Piskorz (2009), envy and schadenfreude are two different and independent concepts determined by different situations.

This study proposes a new perspective about social envy and schadenfreude. The first is about their relationships. Indonesian culture contains a personality-like trait called sirik conceptualized as simultaneously manifests envy and schadenfreude perfectly. It consists of the feeling of joy or pleasure when one sees others' fail or suffers misfortune (schadenfreude) and the feeling of unhappiness over others' good fortune (envy). This perspective can resolve the debate about the relationships between social envy and schadenfreude. By seeing them as part of a concept, we can conclude that both are correlated (Cecconi et al., 2020; Hareli \& Weiner, 2002; van de Ven \& Zeelenberg, 2015). However, this perspective also allows us to understand that situations can influence envy and schadenfreude (Piskorz \& Piskorz, 2009). More specifically, there may be a situation where envy functions, while schadenfreude does not, and vice versa, leading to the absence of correlation between them (Feather \& Sherman, 2002).

Second, as part of the same personality-like trait, from the envied person and schadenfreude target perspectives, envy and schadenfreude are subjects to a stimulation (Smith et al., 1996; Watanabe, 2019). Simamora (202I) found that the willingness to outperform opponents (performance-approach goals) can be stimulated by stimulating the sense of being envied and the effort to avoid failure can be induced by creating a sense of being a schadenfreude target. Opponents are people with whom individuals involve in bidirectional envy and schadenfreude reactions.

This study aims to extend that study by addressing two new approaches. First, the stimulation is conducted to a social group marked by intense rivalry among participants, 
where participants' output rating, not just performance score, is used as the performance indicator that makes one's success reduces other's opportunities to get a promotion, and vice versa. Second, motivation is defined in line with Higgin's self-regulatory focus theory (Higgins, 1998, 2018) as a willingness to increase (promotion focus) and to avoid the decrease (prevention focus) of a competitive position. Therefore, the research question is how the influence of rival's anticipated emotions on the motivation to increase and avoid the decrease of competitive position is? More specifically, the research questions are, first, how is the influence of rivals' anticipated distress on motivation to increase competitive position? Second, how is the influence of rivals' anticipated joyfulness on the motivation to avoid the decrease of competitive position?

These research questions are new to the scientific world. Also, the present study brings some novel perspectives as explained as follows. First, previous studies are past and present-oriented, while this study is present and future-oriented. As we can see in Table I, previous studies described the envy and schadenfreude determinants as past phenomena, whereas envy and schadenfreude and their consequences as the present effects. As their causes have occurred in the past-time, the present-oriented envy and schadenfreude are free from the researcher's intervention. This study takes a different perspective in which schadenfreude and social envy are future phenomena caused by future scenarios. With this perspective, envy and schadenfreude can be intervened by the researcher by manipulating the controllable situation (Parks et al., 2002; Smith et al., 1996). 
Table I

Selected Social Envy and Schadenfreude Studies and Their Findings

\begin{tabular}{|c|c|c|c|c|c|}
\hline No. & Author & Participants & Source & Perspective & Finding \\
\hline $\mathrm{I}$ & $\begin{array}{l}\text { Smith et al. } \\
(1996)\end{array}$ & Students & $\begin{array}{l}\text { Envy and } \\
\text { Schadenfreude }\end{array}$ & $\begin{array}{l}\text { Enviers and } \\
\text { observers }\end{array}$ & $\begin{array}{l}\text { Schadenfreude will result when an } \\
\text { envied person from average and } \\
\text { superior position experiences } \\
\text { misfortune }\end{array}$ \\
\hline 2 & $\begin{array}{l}\text { Feather \& } \\
\text { Sherman, } \\
(2002)\end{array}$ & $\begin{array}{l}\text { Undergraduate } \\
\text { students with } \\
\text { high and average } \\
\text { achievement }\end{array}$ & Schadenfreude & Observers & $\begin{array}{l}\text { Schadenfreude about the student's } \\
\text { failure was predicted by resentment. } \\
\text { It is stronger when the targets are } \\
\text { perceived to deserve the failure for } \\
\text { applying low effort that the process. }\end{array}$ \\
\hline 3 & $\begin{array}{l}\text { Hareli \& } \\
\text { Weiner } \\
(2002)\end{array}$ & General people & $\begin{array}{l}\text { Envy and } \\
\text { Schadenfreude }\end{array}$ & $\begin{array}{l}\text { Enviers and } \\
\text { Observers }\end{array}$ & $\begin{array}{l}\text { Besides envy, other-directed negative } \\
\text { emotions (e.g., dislike and anger) also } \\
\text { work as a determinant of } \\
\text { schadenfreude }\end{array}$ \\
\hline 4 & $\begin{array}{l}\text { Parks et al. } \\
(2002)\end{array}$ & $\begin{array}{l}\text { Inter-groups } \\
\text { outcomes } \\
\text { comparison }\end{array}$ & Envy & Enviers & $\begin{array}{l}\text { If the result obtained is lower than } \\
\text { the opponent, people show less } \\
\text { motivation to cooperate, and vice } \\
\text { versa. Reducing the outcomes } \\
\text { difference accompanied by the } \\
\text { justification for the difference have a } \\
\text { small effect on reducing envy }\end{array}$ \\
\hline 5 & $\begin{array}{l}\text { Piskorz \& } \\
\text { Piskorz } \\
\text { (2009) }\end{array}$ & General people & Schadenfreude & Observers & $\begin{array}{l}\text { Schadenfreude is more associated } \\
\text { with the failure of close than } \\
\text { unknown persons }\end{array}$ \\
\hline 6 & $\begin{array}{l}\text { Cohen- } \\
\text { Carash \& } \\
\text { Mueller } \\
(2007)\end{array}$ & General people & Social envy & Enviers & $\begin{array}{l}\text { Benign envy leads to self- } \\
\text { improvement followed by socially- } \\
\text { desirable behavior. Malicious-envy } \\
\text { generates a willingness to harm the } \\
\text { envied person and is followed by } \\
\text { undesirable social behavior. }\end{array}$ \\
\hline 7 & $\begin{array}{l}\text { van de Ven } \\
\text { et al. (2009) }\end{array}$ & $\begin{array}{l}\text { General people } \\
\text { from } \\
\text { Netherland, } \\
\text { USA, and Spain }\end{array}$ & Social Envy & Enviers & $\begin{array}{l}\text { Benign envy leads to moving-up } \\
\text { motivation aimed at improving one's } \\
\text { own position. }\end{array}$ \\
\hline & & & & & $\begin{array}{l}\text { Malicious envy creates pulling-down } \\
\text { motivation aimed at damaging the } \\
\text { envied person's position }\end{array}$ \\
\hline 8 & $\begin{array}{l}\text { Van de Ven } \\
\text { et al. }(20 I I)\end{array}$ & $\begin{array}{l}\text { iPhone } \\
\text { consumers }\end{array}$ & Social Envy & Enviers & $\begin{array}{l}\text { The envy premium occurs when the } \\
\text { enviers compare their-selves to the } \\
\text { superior one. This comparison } \\
\text { generates benign envy when the } \\
\text { reference deserves the prestigious } \\
\text { object and malicious envy when they } \\
\text { do not }\end{array}$ \\
\hline
\end{tabular}

(continued) 
Table I (continued)

Selected Social Envy and Schadenfreude Studies and Their Findings

\begin{tabular}{|c|c|c|c|c|c|}
\hline No. & Author & Participants & Source & Perspective & Finding \\
\hline 9 & $\begin{array}{l}\text { Van de Ven } \\
\text { et al.(20II) }\end{array}$ & Students & Social envy & Enviers & $\begin{array}{l}\text { Benign envy generates admiration. It } \\
\text { is the benign envy, not the } \\
\text { admiration, that influences motivation } \\
\text { to move up }\end{array}$ \\
\hline 10 & $\begin{array}{l}\text { Hellén \& } \\
\text { Sääksjärvi(20 } \\
\text { I3) }\end{array}$ & Students & Social Envy & Enviers & $\begin{array}{l}\text { Benign envy and malicious envy are } \\
\text { closely related. Benign envy can turn } \\
\text { to be malicious envy for people who } \\
\text { are concerned about their social } \\
\text { status in comparison to other }\end{array}$ \\
\hline II & $\begin{array}{l}\text { van de Ven } \\
\& \\
\text { Zeelenberg } \\
(2015)\end{array}$ & Workplace & Social envy & Enviers & $\begin{array}{l}\text { Counterfactual thinking, defined as it } \\
\text { could have been me, is more } \\
\text { associated with social envy }\end{array}$ \\
\hline 12 & $\begin{array}{l}\text { Apple et al. } \\
(2015)\end{array}$ & $\begin{array}{l}\text { University } \\
\text { students }\end{array}$ & Social envy & Enviers & $\begin{array}{l}\text { In depressed individuals, low self- } \\
\text { esteem and high inferiority correlate } \\
\text { strongly with envy. }\end{array}$ \\
\hline 13 & $\begin{array}{l}\text { Lange \& } \\
\text { Crusius } \\
(2015)\end{array}$ & $\begin{array}{l}\text { General } \\
\text { people }\end{array}$ & Social envy & $\begin{array}{l}\text { Envied } \\
\text { persons }\end{array}$ & $\begin{array}{l}\text { Authentic (success attributed to } \\
\text { effort) and hubristic pride (success } \\
\text { attributed to talent) modulate } \\
\text { envious intentions), and behavior } \\
\text { toward their benign and malicious } \\
\text { form, mainly when the authentic and } \\
\text { hubristic pride are expressed by } \\
\text { superior people based on their real } \\
\text { experience in a competitive situation. }\end{array}$ \\
\hline 14 & $\begin{array}{l}\text { Thompson } \\
\text { et al. }(2016)\end{array}$ & Workplace & Envy & Enviers & $\begin{array}{l}\text { The supervision span is the } \\
\text { antecedent of envy. It is significantly } \\
\text { correlated to envy via supportive } \\
\text { leadership. Envy correlates negatively } \\
\text { and indirectly with self-esteem via } \\
\text { distress and directly to social loafing }\end{array}$ \\
\hline 15 & $\begin{array}{l}\text { Brambilla \& } \\
\text { Riva (2017) }\end{array}$ & $\begin{array}{l}\text { General } \\
\text { people }\end{array}$ & Schadenfreude & Observers & $\begin{array}{l}\text { Satisfaction toward the target } \\
\text { misfortune is higher in a competitive } \\
\text { than a less-competitive situation. The } \\
\text { higher the schadenfreude feeling, the } \\
\text { higher the tendency to observe } \\
\text { others' misfortune. }\end{array}$ \\
\hline 16 & $\begin{array}{l}\text { Van de Ven } \\
(2017)\end{array}$ & $\begin{array}{l}\text { General } \\
\text { people }\end{array}$ & Social envy & Enviers & $\begin{array}{l}\text { Envy followed by admiration to the } \\
\text { envied persons stimulate motivation } \\
\text { to improve the self. }\end{array}$ \\
\hline
\end{tabular}

(continued) 
Table I (continued)

Selected Social Envy and Schadenfreude Studies and Their Findings

\begin{tabular}{|c|c|c|c|c|c|}
\hline No. & Author & Participants & Source & Perspective & Finding \\
\hline 17 & $\begin{array}{l}\text { Meier and } \\
\text { Schafer } \\
(2018)\end{array}$ & $\begin{array}{l}\text { Social media } \\
\text { network } \\
\text { Instagram }\end{array}$ & Social envy & Enviers & $\begin{array}{l}\text { Benign envy creates inspiration that } \\
\text { generates positive affect }\end{array}$ \\
\hline \multirow[t]{2}{*}{18} & $\begin{array}{l}\text { Lin et al. } \\
(20 \mid 8)\end{array}$ & $\begin{array}{l}\text { Social } \\
\text { network } \\
\text { society }\end{array}$ & Social envy & Enviers & $\begin{array}{l}\text { Experiential purchase triggers envy } \\
\text { more strongly than material purchase } \\
\text { because it is more relevant to self- } \\
\text { image. }\end{array}$ \\
\hline & $\begin{array}{l}\text { Watanabe } \\
(2019)\end{array}$ & $\begin{array}{l}\text { University } \\
\text { students }\end{array}$ & Schadenfreude & Observers & $\begin{array}{l}\text { Sharing schadenfreude with a best } \\
\text { friend does not affect the increases in } \\
\text { self-esteem, nor a sense of being } \\
\text { understood and social acceptance. }\end{array}$ \\
\hline 19 & $\begin{array}{l}\text { Cecconi et } \\
\text { al. }(2020)\end{array}$ & $\begin{array}{l}\text { Facebook, } \\
\text { Twitter, and } \\
\text { Instagram }\end{array}$ & Schadenfreude & Observers & $\begin{array}{l}\text { Spatial or factual distance have a low } \\
\text { correlation with Schadenfreude }\end{array}$ \\
\hline \multirow[t]{2}{*}{20} & $\begin{array}{l}\text { Simamora } \\
(2021)\end{array}$ & $\begin{array}{l}\text { University } \\
\text { students }\end{array}$ & Social envy & $\begin{array}{l}\text { Would be } \\
\text { envied persons }\end{array}$ & $\begin{array}{l}\text { Willingness to worst the enviers } \\
\text { stimulate performance-approach } \\
\text { goals. }\end{array}$ \\
\hline & & & Schadenfreude & $\begin{array}{l}\text { Would be } \\
\text { schadenfreude } \\
\text { targets }\end{array}$ & $\begin{array}{l}\text { In a competitive social environment, } \\
\text { willingness to avoid a feeling of joy } \\
\text { appeared as opponents' } \\
\text { schadenfreude manifestation, improve } \\
\text { performance-avoidance goals }\end{array}$ \\
\hline \multirow[t]{2}{*}{21} & $\begin{array}{l}\text { Simamora } \\
\text { (present } \\
\text { study) }\end{array}$ & $\begin{array}{l}\text { Any } \\
\text { competitive } \\
\text { social groups }\end{array}$ & Social envy & $\begin{array}{l}\text { Would be } \\
\text { envied persons }\end{array}$ & $\begin{array}{l}\text { In a competitive social environment, } \\
\text { willingness to worst rivals will } \\
\text { increase motivation to improve } \\
\text { rating-based performance. }\end{array}$ \\
\hline & & & Schadenfreude & $\begin{array}{l}\text { Would be } \\
\text { schadenfreude } \\
\text { target }\end{array}$ & $\begin{array}{l}\text { Willingness to avoid rivals' feelings of } \\
\text { joy will strengthen motivation to not } \\
\text { lose or maintain a rating-based } \\
\text { position. }\end{array}$ \\
\hline
\end{tabular}

Second, as stated by (Aquaro, 2004), most of the previous studies focused on the negativity of envy and schadenfreude (e.g., Brambilla \& Riva, 2017; Hareli \& Weiner, 2002; Piskorz \& Piskorz, 2009) their causes (e.g., Apple et al., 2015; Feather \& Sherman, 2002; Lin et al., 20I8) and consequences (e.g., Brambilla \& Riva, 2017; Cecconi et al., 2020; Watanabe, 2019). Later, the scientists introduced benign envy. Although viewed as softer, this category still contains negative emotions that may generate positive effects, such as admiration and motivation narrow the gap, but only when the enviers see no possibility to match or beat the envied persons (Lange \& Crusius, 20I5; Meier \& Schafer, 20I8; van de Ven, 2017).

Third, the previous studies depended heavily on the direct method to measure social envy and schadenfreude. Due to the negativity of envy and schadenfreude, this method contains a potential bias because, when making a self-report about their selves, the people (the enviers 
or observers) tend to reduce their self-negativity to increase self-desirability (Althubaiti, 2016). The present study used an indirect method by measuring anticipate rivals' distress and joyfulness in responding would be envied persons' success and would be the schadenfreude target failure. Anticipation contains lesser bias because it is based on prior experiences and knowledge (Bozinovski \& Bozinovska, 2003). Also, people have the capability to detect others' emotions (Baumeister et al., 2007; Simamora, 202I) and can give more accurate enviers' emotional response to their success or failure. Fourth, most of the previous studies investigated social envy and schadenfreude separately as they are viewed as two separated concepts. This study takes a different approach, in which, as situational induced emotions (Hellén \& Sääksjärvi, 20I3), both can be activated separately or simultaneously.

The author expects that this study contributes in two ways. First, this study is the first to conceptualize rivals' anticipated emotions as the envy and schadenfreude manifestations. Hopefully, this new concept can enrich the scientific world. Second, the proposed model is hopefully useful for those who concern, such as teachers and school management, to manipulate rivals' anticipated emotions to some extent to optimally stimulate achievement motivation.

\section{Literature Review}

Social Envy

Humans are inseparable from one another. In social life, others consist of significant others (Icek Ajzen, 2020) and 'rivals' (Celse, 2010) or opponents (Simamora, 202I). Significant others are people that are important in one's life (Icek Ajzen, 2020). Rivals are people with whom an individual has openly or silently anti-social relationships (Celse, 2010). The 'enemies' existence gave birth to the social envy concept (Celse, 2010; Smith \& Kim, 2007). Social envy appears when someone witnesses that the envied persons or group have a valuable object, which produces the feeling of inferiority and resentment (Smith \& Kim, 2007; van de Ven et al., 2009). It stems from an upward comparison, in which someone (the enviers) compares himself or herself to a superior person (the envied) in terms of the ownership of the envied object (van de Ven et al., 2009). Envy is generated not by the fact that the rival does well but does better than oneself. Such an evaluation generates a 
collection of emotions during its episode that may include a feeling of inferiority, hatred to the situations, and bad feelings toward the envied person (Parrot \& Smith, 1993).

Envy behavior involves three components: the envier, the envied person, and the envied object (Lange et al., 2018). The envy objects can be an achievement, characteristic, or possession with high prestige value and strongly relate to the envied social status (Lange et al., 2018; Lange \& Crusius, 2015).The theory of social envy still evolves these days. There are three issues as research traditions in this field. They are the categories of social envy (e.g., Falcon, 2015; van de Ven et al., 2009), antecedents (Lange \& Crusius, 20I5; Lin et al., 20I8), consequences (van de Ven, 2016), or antecedents and consequences (Apple et al., 2015).

The enviers have two faces. The first is a more negative face called malicious envy (van de Ven et al., 2009). With this face, envy is a destructive feeling that harmful to the envier physically, psychologically, and behaviorally. Malicious envy exists simultaneously with schadenfreude (Hareli \& Weiner, 2002; Smith \& van Dijk, 2018). Social envy can generate schadenfreude (Hareli \& Weiner, 2002; Smith \& van Dijk, 2018). It can also produce aggressive behaviors and conflicts in groups (Cohen-Carash \& Mueller, 2007) and willingness to bring down the other (Tai et al., 20I2), including increasing motivation to reduce or remove or damage others' prospect and advantages. However, for these reasons, one's situation may be sacrificed (Parks et al., 2002).

The second face of social envy that receives a more positive view describes that the enviers increase their motivation to work harder to get what the envied persons already have (van de Ven, 2016; van de Ven et al., 2009). Lange et al. (2018) stated that the enviers' motivation is accompanied by positive thoughts about and admiration of the envied person. Van de Ven (2016) noted that the antecedents of envy could be the same, but the enviers' reactions may differ because of the differences in individual characteristics. Vecchio (1995) stated that the particular tendency over envy was also determined by envied object characteristics, cultural attributes, and the situation where the envy occurred in addition to personal properties. Lange et al. (2018) underlined that envy influences consumer behavior, the social structure of an organization, the perception of one's body, virtual emotional experience, the 
development of stereotypes, and many aspects of human psychology. That is why, they said, some people believe that envy shapes the entire society.

\section{Schadenfreude}

Schadenfreude is the joy experienced by individuals when observing others' misfortunes. It is typically happening in competitive circumstances (Smith et al., 2009), correlates with selfesteem (van Dijk et al., 20II), and occurs at individual and group levels (Brambilla \& Riva, 2017). Schadenfreude can be caused by a threat to one's self-worth (van Dijk et al., 20I5) and others' success (Leach \& Spears, 2008). Among them, self-inferiority is the strongest (Leach \& Spears, 2008), especially if the object correlates with self-esteem sources (Watanabe, 2019).

At the individual level, people with low self-esteem feel thicker and more frequent schadenfreude, especially if the persons who suffer from misfortunes perceived as superiors (van Dijk et al., 20II). At a group level, group inferiority generates group schadenfreude. It creates a feeling of joy for the misfortune of a successful outgroup (Leach \& Spears, 2008). The reverse is also true. People with high self-esteem feel weaker and less frequent schadenfreude, especially if the persons who experience misfortune are from an inferior position (van Dijk et al., 20II). Ouwerker and Johnson (2016) also demonstrated that strong schadenfreude is also evident in social media (e.g., Facebook, Instagram, and Twitter). They said that in media, to maintain positive evaluation, people tend to make downward social comparisons with those who have a lower social status or are less fortunate than themselves.

Schadenfreude is a socially undesirable emotion. Individuals who express those emotions to the people around them tend to be perceived as immoral, incompetent, and heartless (Jung \& Karasawa, 2016). They face the risk of deteriorating relationships with the target of schadenfreude, as well as the people around them (Watanabe, 2019). However, Watanabe (2019) noted that sharing schadenfreude with a close friend or with those who have the same emotions is possible. 
There are four conditions in which schadenfreude commonly arise. First, when the observers get gain from others' misfortune. When a rival's failure opens an opportunity or gives an observer gain, schadenfreude tends to occur (Smith et al., 2009).

Second, schadenfreude tends to occur when observers see that others deserve the misfortune because of their hypocrisy or sense of injustice over a person who suffers from the misfortune (Smith et al., 2009). In this way, the observers view the misfortune as a logical answer to that hypocrisy and injustice.

The third condition, if the misfortune is experienced by envied persons or those in a superior position. Van Dijk et al. (20II) reported that self-esteem would decrease when people suffer from misfortunes. At the same time, the observers will feel an increase in their self-esteem. Therefore, the envied persons' misfortune will bring both parties' self-esteem to a more balanced comparison. The fourth condition, as Feather, and Sherman (2002) said, schadenfreude is geared up by the observer's resentment toward the misfortune persons.

\section{Rivals' Anticipated Emotions}

In this study, the author sharpens the Simamora's (202I) notion by addressing the competition to a more formal social group when the performance is counted from individuals' competence and comparative achievement. We can find it in school, university, military, course, training, and audition, especially when the opportunity to become a winner is a limited commodity. In such a society, the achievement is often counted not only as a prestigious object but also as a ticket to get a limited and valuable opportunity for a promotion. For example, in senior high school, it is generally found that individuals' grade point average (GPA) and the GPA rank are vital indicators for students' opportunity to enter the dreaming faculty at a famous university through a free test system. The higher the GPA and its ranking, the higher the students' opportunity. Therefore, an individual's good achievement could be 'bad news' to others and vice versa. The students watch each other and expect excellent achievement for the self and lousy achievement for others that gave birth to more real envy and schadenfreude presence. 
Simamora (2021) extended Mayer and Salovey's (1997) emotional intelligence theory that people can anticipate opponents' emotions in responding to their success or failure to establish tasks or achieve goals. Opponents are those with whom individuals involving in a social competition that functions as a natural spectacle for social envy and schadenfreude. This study sees that the notion is more apparent when the competition occurs among peers ina scramble for comparative achievement as described above. In such a situation, individuals can anticipate rivals' positive emotions (such as pleasure, happiness, release, satisfaction, joyfulness, and excitement) for their failure or defeat. They also can anticipate rivals' negative emotions (such as dislike, unhappy, uncomfortable, scornful, jittery, and cynical) for their success or win. The author calls those future-oriented emotions as anticipated emotions of rivals (RAE). For simplification reason, the author the positive category as rivals' anticipated joyfulness (RAJ) and the negative one as rivals' anticipated distress (RAD).

Anticipation is a readiness to face predicted future events generated primarily by a cognitive skill (Bozinovski \& Bozinovska, 2003) that can be occurred in a very short or very long time (Poli, 2010). It often deals with the consequences of behavior for the self-image and emotions in the future (Eskritt et al., 20l4). The more experienced the individual, the more accurate the anticipation is (Bozinovski \& Bozinovska, 2003). With this view, the author proposes that the RAE are the emotions one anticipates or be ready to face due to one's future success or failure in a race-like social competition.

Which rivals' emotions are anticipated depend on individuals' position in a social competition? Envied persons should be those who have a significant opportunity to win the competition or to beat their rivals for the feeling of win. People in this position have the advantage of superiority (Smith et al., 2009). On the other hand, people who have a high risk of failure know that they can be the target of rivals' schadenfreude and try to get rid of it by avoiding failure.

Individuals with high efficacy should apply approach motivation by pursuing success or win, enabling them to envy the enviers. Those with low efficacy will apply avoidance motivation by which they avoid a failure or defeat that may cause them to become schadenfreude target. 
The first goal, owned by people with high self-efficacy is counted from a downward social contrast. The second goal, owned by people with low self-efficacy, is produced by upward social comparison. People in the average position can involve in upward and downward social comparison simultaneously. Consequently, in the context of a social relationship, people can have positive and negative RAE that are motivated by approach, avoidance, or approach and avoidance motivation at the same time (Darnon et al., 2009).

\section{Achievement Motivation}

Atkinson (1957) defined achievement as the comparison of one's performances with others or against a certain standard of activities. He specified three factors that determine the tendency to approach achievement-related goals: the need for achievement or motive for success, probability of success to achieve the goals, and incentive value of success. In the same tone, when approaching achievement motivation, Nicholls (1984) and Ames (1992) stated achievement goals as the expected outcomes generated by skill-related factors of high ability or self-efficacy people. With this understanding, they further underlined that people might only be motivated to master a task (mastery goals) or beat others (performance goals).

When bringing the concept to the educational context, Elliot (1999) added a goal to represent a willingness not to become a loser called performance-avoidance goals. With this additional goal orientation, he offered the trichotomous goals. It consists of mastery goals (an effort to improve task-related skill or competence), performance-approach goals (intended to get others' admiration because of one's relative high competence), and performance avoidance-goals (an effort to avoid being perceived as less competent). He believed that those who have high self-efficacy should own the first two goals, and low self-efficacy should own the third category.

In 200 I, Elliot and McGregor added the fourth dimension called mastery avoidance, in which an individual thought to avoid failure in mastering a skill or competence. With this additional goal, the new model is called the $2 \times 2$ model that consists of a mastery-approach, masteryavoidance, performance-approach, and performance-avoidance goals. Many studies confirm this model's validation (Huang, 2016; Rosas, 2015). The first two goals categories are 
connected with the mastering of materials. The second two goals that are also called ego goals, occur in terms of the comparison of one's performance to others (DoménechBetoret et al., 2017; van Yperen, 2006).

Achievement goals discussed above are connected with a final result of a task establishment. They are absent from individual's step-by-step progress in their effort to get the final result. Therefore, in this study, the ego goals used as success and failure indicators are defined in terms of Higgins' regulatory focus theory (Higgins, 1998, 2018). This theory asserts that, because of their resources limitation, people will focus exclusively on promotion or prevention. In promotion focus, people see success as getting a 'gain' and failure as getting 'no gain.' In prevention focus, failure is perceived as 'loss' and success as 'no loss.' In this study, where the students' ratings are used as a success indicator, the 'gain' means the increase of current competitive position or rating, 'no gain' means fail to increase the current competitive position. The 'lose,' or failure is compatible with the decrease of the current competitive position. The condition of 'not lose,' interpreted as a success, means no change in the current competitive position.

\section{Conceptual Model and Propositions}

In responding to future schadenfreude and envy, the author postulates that an individual involves in a non-static but dynamic goal-directed behavior. Because, with future-oriented thinking, people can predict their behavior's desired and undesired outcomes (Ajzen \& Madden, 1986; Michelle Eskritt et al., 2014). When an individual wants to get or avoid them, the desired or undesired outcomes become goals (Ajzen \& Madden, 1986).

The demonstration aspect places achievement motivation as one of the envy objects (Lange et al., 2018; van de Ven \& Zeelenberg, 2015). Precisely, in a social competition where the sirik trait works, people are capable of figuring out and anticipate rivals' joyfulness when they fail to reach the achievement they deserve or fall below the rivals' grade (Simamora, 202I). 


\begin{tabular}{|c|c|c|c|}
\hline $\begin{array}{c}\text { Rivals' Anticipated } \\
\text { Joyfulness }\end{array}$ & $\begin{array}{c}\text { Willingness to Avoid } \\
\text { become the } \\
\text { Schadenfreude Target }\end{array}$
\end{tabular}$\longrightarrow \begin{gathered}\text { Willingness to Avoid } \\
\text { the Decrease of } \\
\text { Competitive Position }\end{gathered}$

(A)

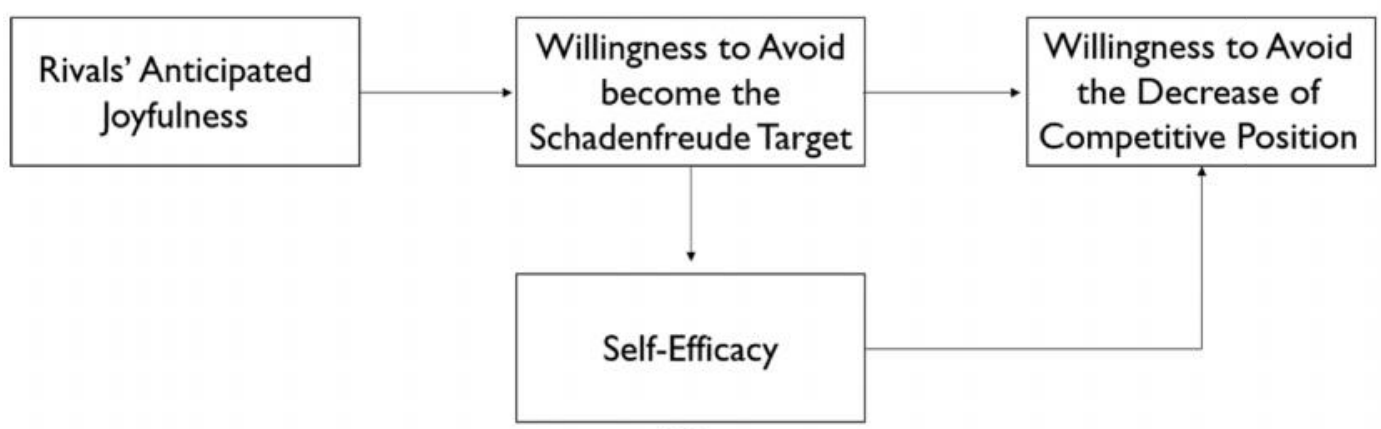

(B)

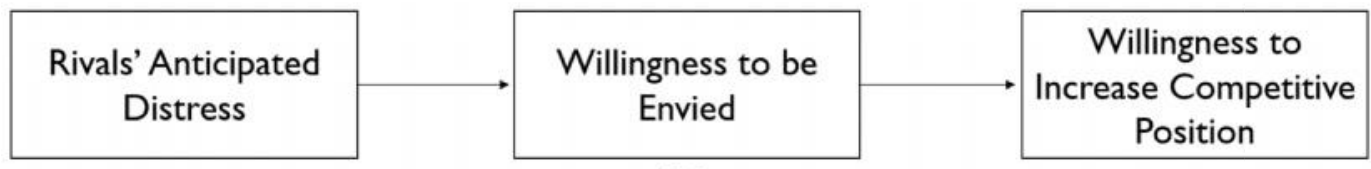

(C)

Figure I.Achievement-Oriented Models of Schadenfreude and Social Envy

The works of the sense of being envied and become the schadenfreude target are modeled in Figure I. The model consists of three sub-models. Which sub-model is the most proper one depends on one's position in a competitive group. First, the author divides competitive positions into three classes; they are upper, medium, and lower positions. Those in the average and superior position are the most possible target of schadenfreude (Lange \& Crusius, 2015; Smith et al., 1996; van Dijk et al., 201I) and care more firmly on the decreasing than the increasing of achievement. In Higgin's regulatory focus theory (Higgins, 1998, 2018), the focus on prevention. Therefore, because of the sense of being target (Figure IA), they will avoid the decrease of the current competitive position, such as stated in the following proposition:

PI: When stimulated with rivals' anticipated joyfulness, students in the average and superior position increase higher willingness to avoid being the schadenfreude target, by avoiding the decrease current competitive position, than those who are in the lower positions. 
For those in the lower position, increasing the position is the most exciting target of them. In Higgin's (1997) self-regulatory focus theory, they will see a 'gain' or success as the increase of competitive position, and 'no-gain' or remaining in the current low position as a failure. They have been the schadenfreude target for so long, and avoiding that position is less attractive than surprising peers with their position increase. This increase may not envy competitors in upper and medium positions as their positions are far higher and hard to match and overtake, but those who occupy the same low position. Therefore Figure IC is the most proper one for them that inspires the following proposition:

P2: When reminding of rivals' anticipated distress, students in the lower segment will show an increase of willingness to be envied and further the motivation to improve their current competitive position.

People in the average position can have symmetric social comparisons, in which up-ward and down-ward social comparisons are enacted proportionally. However, in this study, future social comparison started from the choice of the reference to compete with. People in the same position are the more relevant reference for that business. To create social envy means to beat the reference and force them to makeup-ward comparisons and consequently feel distressed. The reward is their own satisfaction. Such an achievement enables them to make a downward social comparison or increase the social distance that generates a more positive evaluation of the self (Ouwerker \& Johnson, 2016). People feel happy when they know that their achievements worst for others (Fileva, 2020; Smith \& Kim, 2007). Therefore, sense of being envied by those from the same position will increase individuals' motivation to increase competitive position (Figure IC), as stated in the following proposition:

P3: When reminding of rivals' anticipated distress, students' desire to be envied will grow, especially among those from the medium position. Consequently, the motivation to increase their current competitive position will be increased.

Sense of becoming the schadenfreude target may also haunts the people in medium position. Being a loser is an uncomfortable position (Kaplan \& Maehr, 1999). People will regulate their behavior to avoid failure to hinder being the object of rivals' feelings of pleasure, as specified 
in Figure IA. The author believes that the stronger is the rivals' feeling of pleasure, the higher is the individuals' motivation to avoid the failure, as formalized in the following propositions:

P4: When reminding of rivals' anticipated joyfulness, students in the medium position will increase willingness to avoid become the schadenfreude target followed by the increase of performance-avoidance goals.

As stated before, people with high self-esteem feel weaker and less frequent schadenfreude, especially if the persons who experience misfortune are from an inferior position (van Dijk et al., 20ll). Therefore, people in the upper competitive position that viewed as having higher self-efficacy are less likely to make others as schadenfreude targets.

People that need to be watched out by individuals from the medium position are those from the same and lower competitive positions. As the relevant competitors, people in the same competitive position tend to feel happy because the competitors' decrease causes the increase of their competitive position. This is in line with van Dijk et al. (20II) that people tend to experience schadenfreude if others' misfortune gives them an advantage. Van Dijk et al. (201I) also said that people with low self-esteem feel thicker and more frequent schadenfreude, especially if the persons who suffer from misfortunes are from a superior position. These arguments gave birth to the following proposition:

P5: Rivals from the lower and medium competitive positions will have higher anticipated joyfulness as a response to the misfortune of students from the medium position than rivals' from the higher position.

As stated before, people in medium competitive positions symmetrically hold promotion and prevention focus. Grant and Wrzeniewski (2010) also indicated that positive and negative emotions could exist simultaneously in a social context. Performance-approach and performance-avoidance goals can also appear at once (Darnon et al., 2009). Their dominations could vary over time or in different contexts (Harackiewicz et al., 2002; van Yperen, 2006). They may interact to achieve single outcomes (Harackiewizc et al., 2002). Similarly, sense of avoiding being the schadenfreude target (reflected by rivals' anticipated 
joyfulness) and sense of being envied (reflected by rivals' anticipated distress) can be stimulated simultaneously and increase the motivation to avoid the decrease of and to increase competitive position, as stated as follows:

P6: When reminded of rivals' anticipated joyfulness and distress, students in medium positions increase the motivation to avoid the decrease of and to increase competitive position.

\section{Rivals' Anticipated Emotions and Self-Efficacy}

In the gain and lose scenario, schadenfreude can be viewed as lose and the condition of being envied situation as gain. Bosone and Martinez (2017) revealed that framing individuals with a loss would increase self-efficacy. We can understand this finding from Roger's selfprotection theory (Alicke \& Sedikides, 2009; Rogers, 1975) which specifies that individuals will increase their self-efficacy when confronted with fear or threat. Self-efficacy is a belief hold by an individual that he or she is capable of establishing a task or achieve goals (Bandura, 1977; Darnon et al., 2009; Hsieh et al., 2007). In terms of students' rivalry, the decrease of competitive position feared to induce rivals' schadenfreude will increases selfefficacy as part of an unconscious effort to protect the self, as stated in the following proposition:

P7: Rivals' joyfulness, anticipated as a response to individuals' competitive position decrease, increases self-efficacy.

Bosone and Martinez (2017) further stated that framing with gain has a weak effect on efficacy belief. The scenario of being envied positions students as the winner or high efficacy people that require no additional effort to cover the weakness. In other words, an anticipated success that generates a feeling of being envied does not affect self-efficacy, as stated as follows:

P8: For students in a medium and lower position, rivals' distress, anticipated as a response to their competitive position increase, gives no effect on self-efficacy. 
Since its birth, scientists have addressed that the very impact of self-efficacy is achievement motivation (Ames, 1992; Bandura, 1977; Darnon et al., 2009; Nicholls, 1984). Therefore, self-efficacy specified as increased by rivals' anticipated joyfulness will lead to the increase of achievement motivation. In other words, self-efficacy can also have a mediating function to the relationship specified in Proposition 7, as formulated in the following proposition:

P9: For students in a medium competitive position, self-efficacy mediates the influence of rivals' anticipated joyfulness on motivation to increase competitive position.

\section{Discussion}

This study proposes the conceptual validity of rivals' anticipated emotions (RAE) expected to influence rank-based achievement goals. The RAE indicates the existence of futureoriented social envy and schadenfreude among peers in a competitive situation. The most important thing is, this study describes how people anticipate the RAE and use the sense of being envied and become schadenfreude to regulate their current effort to increase or avoid the decrease of competitive position. Indirectly, this study's results also enrich our knowledge of two new motives that drive achievement motivation; they are a motive to worst rivals and avoid being the target of schadenfreude.

The RAJ and RAD are not two poles. They are two different categories of emotions that do not negate each other, as outlined by Roseman (1991). Automatically, the need to be envied and avoided being the schadenfreude target are two different and independent motives. This prescription strengthens Piskorz and Piskorz's (2009) statement that social envy and schadenfreude are two different and independent concepts that are determined by different situations. However, this notion does not negate that social envy and schadenfreude are part of the same personality-trait proposed in this study, as they are naturally co-existed (Cecconi et al., 2020; Piskorz \& Piskorz, 2009) and correlated (Hareli \& Weiner, 2002; Smith \& van Dijk, 20I8; van de Ven \& Zeelenberg, 20I5).

This study formulates the sole and mutual influence of the RAJ and RAD, conceptualized as the manifestation of social envy and schadenfreude, on achievement motivation in Higgin's 
(Higgins, 1998, 2018) self-regulatory framework. Specifically, the RAJ, as the manifestation of fear of being a schadenfreude target, increases the motivation to avoid the decrease of competitive position (prevention focus). The RAD that functions as the reflection of willingness to be envied stimulates motivation to increase competitive position (promotion focus). Finally, the RAJ and RAD can work simultaneously. This viewpoint covers previous studies (e.g., Grant \& Wrzeniewski, 20I0; Nikitin \& Freund, 2018) that outlined the coexistence of approach and avoidance motivations. It is also in line with van Yperen's (2006) prescription that most people prefer a particular achievement goal, a dominant achievement goal that could vary over time and be activated by different contexts. Up to this point, we can see that, concerning future schadenfreude and envy, achievement motivation is not a static but a dynamic concept.

This study asserts that the RAJ and RAD influence ego-oriented, not mastery-oriented goals. It means that concerning achievement motivation, social envy, and schadenfreude only care for relative performance among peers, not the real skills, knowledge, or competencies generated from learning or task accomplishment. This result strengthens the notion that social envy and schadenfreude belong to a social comparison of self-esteem linked with material possessions (van de Ven, 2016; van de Ven \& Zeelenberg, 20I8; van Dijk et al., 20I5).

There is a debate about the relationships between self-efficacy and achievement motivation. Some researchers found a positive relationship (Anderman \& Miggley, 1997; Darnon et al., 2009; Pajares et al., 2000) between them; others found no correlation (Anderman \& Miggley, 1997; Middleton \& Miggley, 1997). This study proposes a new challenge to investigate whether, in the loose scenario, self-efficacy mediates the influence of rivals' anticipated joyfulness on achievement motivation. It is also interesting to verify that when people focus on the gain generated by a feeling of being envied, self-efficacy is not needed to increase performance-approach goals.

Tian et al. (2017) found that performance-avoidance goal orientations correlate negatively with well-being. Tuominen-Soini et al. (2008) uncovered that goals purposed to demonstrate one's performance (i.e., performance-approach goals) correlates negatively 
with psychological well-being. It is an exciting challenge for further research to investigate the correlation of RAJ and RAD with psychological well-being.

This study is still limited to the individual level of RAE. Since social envy and schadenfreude also work on the group level (Brambilla \& Riva, 2017; Leach \& Spears, 2008; Watanabe, 2019), further research is suggested to study the influence of RAE to group motivation. In this study, which departed from the Indonesian cultural concept called sirik, the author proposes that social envy and schadenfreude are the dimensions of a personality trait. This premise can be a challenging area of investigation for further research.

\section{Conclusion}

This study conceptualizes the efficacy of rivals' anticipated emotions as the manifestation of social envy and schadenfreude. The model specifies that willingness to envy others and avoid being the schadenfreude target is manifested in rivals' anticipated emotions. Rivals' anticipated joyfulness as the manifestation of schadenfreude upon subjects' failure increase self-efficacy and performance-avoidance goals. A part of performance-avoidance goals is contributed by self-efficacy increase. Moreover, rivals' anticipated distress, anticipated as an unconscious response to students' success, stimulates performance-approach goals and does not affect self-efficacy. Both emotions do not influence the mastery approach and avoidance goals.

\section{Acknowledgment}

The author acknowledges that the Institute of Research and Community Service of Kwik Kian Gie School of Business and Information Technology supports this study financially. 


\section{References}

Ajzen, I., \& Madden, T. J. (1986). Prediction of goal-directed behavior: Attitudes, intentions, and perceived behavioral control. Journal of Experimental Social Psychology, 22(5), 153474. https://doi.org/10.1016/0022-1031(86)90045-4

Ajzen, Icek. (2020). The theory of planned behavior: Frequently asked questions. Human Behavior and Emerging Technologies, 2(4), 314-324. https://doi.org/I0.1002/hbe2. 195

Alicke, M. D., \& Sedikides, C. (2009). Self-enhancement and self-protection: What they are and what they do. Journal of Social Psychology, 20(I), I-48. https://doi.org//0.1080/104632808026/3866

Althubaiti, A. (2016). Information bias in health research: Definition, pitfalls, and adjustment methods. Journal of Multidisciplinary Healthcare, $21 \mathrm{l}$. https://doi.org//0.2147/JMDH.SI 04807

Ames, C. (1992). Classrooms: Goals, structures, and student motivation.Journal of Educational Psychology, 84(3), 26 I-27I. https://doi.org/I0.1037/0022-0663.84.3.26 I

Anderman, E. M., \& Miggley, C. (1997). Changes in achievement goal orientations, perceived academic competence, and grades across the transition to middle-level schools. Contemporary Educational Psychology, 22(3), 269-298. https://doi.org// 0.1006/ceps.1996.0926

Apple, H., Crusius, J., \& Gerlach, A. L. (20I5). Social comparison, envy, and depression on Facebook: A study looking at the effects of high comparison standards on depressed individuals. Journal of Social and Clinical Psychology, 34(4), 277-289. https://doi.org/I0.152I/jscp.20I5.34.4.277

Aquaro, F. G. (2004). Death by Envy. The Evil Eye and Envy in Christian Tradition. iUniverse, Inc.

Atkinson, J. W. (1957). Motivational determinants of risk-taking behavior. Psychological Review, 64(6), 359-372. https://doi.org/10.1037/h0043445

Bandura, A. (1977). Self-efficacy: Toward a unifying theory of behavioral change. Psychological Review, 84(2), 19I-2I5. https://doi.org/I0.1037/0033-295X.84.2.191

Baumeister, R. F., Vosh, D., DeWall, C. N., \& Zhang, L. (2007). How emotions shapes behavior. Personality and Social Psychology, II, I67-203.

Bosone, L., \& Martinez, F. (2017). When, how and why is loss-framing more effective than gain- and non-gain-framing in the promotion of detection behaviors? International Review of Social Psychology, 30(I), 184-192. https://doi.org// 0.5334/irsp.I5 
Bozinovski, S., \& Bozinovska, L. (2003). Anticipatory behavior in adaptive learning systems. In Anticipatory Behavior in Adaptive Learning Systems (Butz et al., Eds, pp. I-10). Berlin, Germany: Springer

Brambilla, M., \& Riva, P. (20I7). Predicting pleasure at others' misfortune: Morality trumps sociability and competence in driving deservingness and schadenfreude. Motivation and Emotion, 4I, 243-253. https://doi.org//0.1007/s I I03 I-016-9594-2

Cecconi, C., Poggi, I., \& D’Errico, F. (2020). Schadenfreude: Malicious joy in social media interactions. Frontiers in Psychology, II, 558282. https://doi.org// 0.3389/fpsyg.2020.558282

Celse, J. (2010). Sketching envy: From philosophy to psychology. University of Montpellier. http:// www.lameta.univ-montpl.fr/Documents/ DR2010-22.pdf

Cohen-Carash, Y., \& Mueller, J. S. (2007). Does perceived unfairness exacerbate or mitigate interpersonal counterproductive work behaviors related to envy? Journal of Applied Psychology, 92(3), 666-680. https://doi.org/I0.1037/002I-9010.92.3.666

Darnon, C., Dompnier, B., Delmas, F., Pulfrey, C., \& Butera, F. (2009). Achievement goal promotion at university: Social desirability and social utility of mastery and performance goals. Journal of Personality and Social Psychology, 96(I), II9-134. https://doi.org/I0.1037/a0012824

Doménech-Betoret, F., Abellán-Roselló, L., \& Gómez-Artiga, A. (2017). Self-efficacy, satisfaction, and academic achievement: The mediator role of students' expectancyvalue beliefs. Frontiers in Psychology, 8, I 193. https://doi.org//0.3389/fpsyg.2017.01 193

Elliot, A. J. (1999). Approach and avoidance motivation and achievement goals. 34(3), 169-189. https://doi.org//0.1207/s I5326985ep3403_3

Elliot, A. J., \& McGregor, H. A. (200I). A $2 \times 2$ achievement goal framework. Journal of Personality and Social Psychology, 80(3), 50I-519. https://doi.org//0.1037/0022$35|4.80 .3 .50|$

Eskritt, M., J., \& Robitaille, L. (20/4). Does future-oriented thinking predict adolescent decision making? The Journal of Genetic Psychology: Research and Theory on Human Development, I75(2), 63-179.

Eskritt, Michelle, Doucette, J., \& Robitaille, L. (20I4). Does future-oriented thinking predict adolescent decision making? The Journal of Genetic Psychology, I75(2), 163-179. https://doi.org//0.1080/0022/325.2013.875886

Falcon, R. G. (20I5). Is envy categorical or dimensional? An empirical investigation using taxometric analysis. 15(6), 694-698. https://doi.org/I0.1037/emo0000 I02. 
Feather, N. T., \& Sherman, R. S. (2002). Envy, resentment, schadenfreude, and sympathy: Reactions to deserved and undeserved achievement and subsequent failure. Personality and Social Psychology Bulletin, 28(7), 953-96I. https://doi.org/I0.I I77/0I46

Fileva, I. (2020, April 19). The desire to be envied: On the moral complexity of a vice and its consequences for happiness. Psychology Today. https://www.psychologytoday.co.

Graham, S., \& Weiner, B. (1996). Theories and principles of motivation. In Handbook of educational psychology (Berliner, D,C, Calve, R.C., Pp. 63-84). Simon \& Schuster McMillan.

Grant, A. M., \& Wrzeniewski, A. (2010). I won't let you down ... Or will I? Core selfevaluations, other-orientation, anticipated guilt and gratitude, and job performance. Journal of Applied Psychology,95(I). https://doi.org/I0.1037/a00 I7974

Harackiewicz, J. M., Barron, K. E., Pintrich, P. R., Elliot, A. J., \& Trach, T. M. (2002). Revision of achievement goal theory: Necessary and illuminating. 94(3), 638-664. https://doi.org//0.1037//0022-0663.94.3.638

Hareli, S., \& Weiner, B. (2002). Dislike and envy as antecedents of pleasure at another's misfortune. Motivation and Emotion, 26, 257-277. https://doi.org/10.1023/A:1022818803399

Hellén, K., \& Sääksjärvi, M. (20I3). Investigating the relationship between benign and malicious envy. In European Advances in Consumer Research (Cornelissen, G., Reutskaja, E., Valenzuale, Duluth, M.N., Vol. 10, pp. I58-159). Association for Consumer Research. https://www.acrwebsite.org/volumes/I013792/volumes/v10e/E10

Higgins, E. T. (1998). Promotion and prevention: Regulatory focus as a motivational principle. Advances in Experimental Social Psychology, 30, I-46. https://doi.org/I0.1016/S0065-260I(08)6038I-0

Higgins, E. T. (2018). What distinguishes promotion and prevention? Attaining “+ I" from "0" as non-gain versus maintaining "0" as non-loss. Psychological Bulletin, 49(I), 40-49. https://doi.org// 0.24425/I 19470

Hsieh, P. (Pei-H., Sullivan, J. R., \& Guerra, N. S. (2007). A Closer look at college students: Self-eficacy and goal orientation. Journal of Advanced Academics, 18(3), 454-476. https://doi.org// 0.4219/jaa-2007-500

Huang, C. (2016). Achievement goals and self-efficacy: A meta-analysis. Educational Research Review, 19, I19-137. https://doi.org/10.1016/j.edurev.2016.07.002 
Jung, K., \& Karasawa, K. (2016). How we view people who feel joy in our misfortune: The influence of expressed schadenfreude in interpersonal situation. Social and Personality Psychology Compass, 30(I), 4I-6I. https://doi.org/I 0.2I I93/kjspp.2016.30.1.003

Kaplan, A., \& Maehr, M. L. (1999). Achievement goals and student well-being. Contemporary Educational Psychology, 24(4), 330-358. https://doi.org/I0.1006/ceps. I 999.0993

Lange, J., \& Crusius, J. (20I5). The tango of two deadly sins: The social-functional relation of envy and pride.Journal of Personality and Social Psychology, 109(3), 354-472. https://doi.org//0.1037/pspi0000026

Lange, J., Weidman, A. C., \& Crusius, J. (20I8). The painful duality of envy: Evidence for an integrative theory and a meta-analysis on the relation of envy and schadenfreude. Journal of Personality and Social Psychology, 1 I 4(4), 572-598. https://doi.org/10.1037/pspi0000II8

Leach, C. W., \& Spears, R. (2008). "A vengefulness of the impotent”: The pain of in-group inferiority and schadenfreude toward successful outgroups. Journal of Personality and Social Psychology, 95(6), I383-1396. https://doi.org//0.1037/a0012629

Lin, R., Van de Ven, N., \& Utz, S. (2018). What triggers envy on social network sites? A comparison between shared experiential and material purchases. Computer and Human Behavior, 85, 27I-28I. https://doi.org/10.1016/j.chb.2018.03.049

Mayer, J. D., \& Salovey, P. (1997). What is emotional intelligent? In Emotional Development and Emotional Intelligent Educational Implications (P. Salovey and D.J. Sluyter, Pp. 3-34). Basic Books.

Meier, A., \& Schafer, S. (2018). The positive side of social comparison on social network sites: How envy can drive inspiration on Instagram. Cyberpsychology, Behavior, and Social Networking, 2 I (7), 4II-4I7. https://doi.org/I0.1089/cyber.2017.0708

Middleton, M. J., \& Miggley, C. (1997). Avoiding the demonstration of lack of ability: An underexplored aspect of goal theory. Journal of Educational Psychology, 89(4), 7I0-718. https://doi.org// 0.1037/0022-0663.89.4.710

Nicholls, J. G. (1984). Achievement motivation: Conceptions of ability, subjective experience, task choice, and performance. 9I(3), 328-346. https://doi.org/I0.1037/0033-295X.91.3.328.

Nikitin, J., \& Freund, A. M. (2018). Feeling loved and integrated or lonely and rejected in everyday life: The role of age and social motivation. Developmental Psychology, 54(6), I I86-I | 98. https://doi.org/I0.1037/dev0000502

Ouwerker, J. W., \& Johnson, B. K. (20I6). Motives for online friending and following: The dark side of social network site connections. Social Media + society, I (JulySeptember), I-19. https://doi.org/I0.II77\%2F2056305 II66642I9 
Pajares, F., Bitner, S. L., \& Valiante, G. (2000). Relation between achievement goals and selfbeliefs of middle school students in writing and science.Contemporary Educational Psychology,25(4), 406-422. https://doi.org/https/doi.org/I0.1006/ceps.1999.1027

Parks, C. D., Rumble, A. C., \& Posey, D. C. (2002). The effects of envy on reciprocation in a social dilemma. Personality and Social Psychology Bulletin, 28(4), 509-520. https://psycnet.apa.org/doi//0.1 I77/0 |46/67202287008

Parrot, W. G., \& Smith, R. H. (1993). Distinguishing the experience of envy and schadenfreude. Journal of Personality and Social Psychology, 64(6), 906-920. https://doi.org/10.1348/01446660I I64704

Piskorz, J. E., \& Piskorz, Z. (2009). Situational determinants of envy and schadenfreude. 40(3), | 37-| 44. https://doi.org/ | 0.2478/s I 0059-009-0030-2

Poli, R. (2010). The many aspects of anticipation. Foresight, 12(3), 7-17. https://doi.org//0.1 108/1463668101 1049839

Rogers, R. W. (1975). A protection motivation theory of fear appeals and attitude change. Journal of Psychology, 9I (I), 93-I I4. https://doi.org/I0.I080/00223980.1975.99I5803.

Rosas, J. S. (2015). Validation of the achievement goal questionnaire - Revised in Argentinean university students. 8(I), I0-23. http://www.scielo.org.co/pdf/ijpr/v8n I/v8n la02.pdf

Roseman, I. (1991). Appraisal determinant of discrete emotions. Cognition and Emotion, 5(3), |6I-200. https://doi.org/| 0.1080/02699939|084| I034

Simamora, B. (202I). How proponents and opponents influence achievement motivation: The role of the anticipated emotions of other people. Gadjah Mada International Journal of Business, 23(I), I-36.https://doi.org/I 0.22 I46/gamaijb.44042

Smith, R. H., \& Kim, S. H. (2007). Comprehending envy. Psychological Bulletin, 133(I), 46-64.

Smith, R. H., Powel, C. A. J., Comb, D. J. Y., \& Schurtz, D. R. (2009). Exploring the when and why of Schadenfreude. Social and Personality Psychology Compas, 3(4), 530-546. https://doi.org/j. I75 I-9004.2009.00I8I.x

Smith, R. H., \& van Dijk, W. W. (2018). Schadenfreude and Gluckschmerz. Emotion Review, I0(4), 293-304. https://doi.org/https//doi.org//0.II77/I7540739/8765657

Smith, R., Turner, T., Garonzik, R., Leah, C., Urch-Druskat, V., \& Weston, C. (I996). Envy and schadenfreude. Personality and Social Psychology Bulletin, 22(2), I58-168. http://hdl.handle.net/2027.42/69046 
Tai, K., Narayan, J., \& McAlister, D. J. (20I2). Envy as pain: Rethinking the Nature of Envy and Its Implications for Employees and Organizations. Academy of Management Review, 37(I), I07-I 29. http://dx.doi.org/I0.5465/amr.2009.0484

Thompson, G., Glasø, L., \& Martinsen, Ø. (2016). Antecedents and consequences of envy. The Journal of Social Psychology, 156(2), I39-153. https://doi.org// 0.1080/00224545.

Tian, L., Yu, T., \& Huebner, E. (2017). Achievement goal orientations and adolescents' subjective well-being in school: The mediating roles of academic social comparison directions.Frontiers in Psychology,8(37), I-I I. https://doi.org/I 0.3389/fpsyg.2017.00037

Tuominen-Soini, H., Salmela-Aro, K., \& Niemivirta, M. (2008). Achievement goal orientations and subjective well-being: $A$ person-centred analysis. Learning and Instruction, I8(3), 25I-266. https://doi.org/I0.1016/j.learninstruc.2007.05.003

Van de Ven, N. (2016). Envy and its consequences: Why it is useful to distinguish between benign and malicious envy. Sociology and Personality Psychology Compass, 10(6), 337349. https://doi.org/I0.1 I I I/spc3.I 2253

Van de Ven, N. (2017). Envy and admiration: Emotion and motivation following upward social comparison. Cognition and Emotion, 37, 193-200. https://doi.or/I0.1080/0269993I.20I5.1087972

Van de Ven, N., \& Zeelenberg, M. (2015). On the counterfactual nature of envy: "It could have been me". Cognition and Emotion, 29(6), 954-97I. https://doi.org//0.1080/0269993 I.2014.957657.

Van de Ven, N., \& Zeelenberg, M. (2018, September 18). Envy and social comparison. https://doi.org/10.31234/osf.io/d2cq9

Van de Ven, N., Zeelenberg, M., \& Pieters, R. (2009). Leveling up and down: The experiences of benign and malicious envy. Emotion, 9(3), 419-429. https://doi.org/I0.1037/a0015669

Van de Ven, N., Zeelenberg, M., \& Pieters, R. (20II). Why envy outperforms admiration. Personality and Social Psychology Bulletin, 37(6), 784-795. https://doi.org//0.1177/0146/6721 |40042।

Van de Ven, Niels, Zeelenberg, M., \& Pieters, R. (20II). The envy premium in product evaluation. Journal of Consumer Research, 37(6), 984-998. https://doi.org//0.1086/657239

Van Dijk, W. W., Ouwerker, J. W., Goslinga, S., Nieweg, M., Smith, R. H., \& Cikara, M. (2006). When people fall from grace: Reconsidering the role of envy in schadenfreude. Emotion, 6(I), I56-160. https://doi.org/I0.1037//528-3542.6.I.156 
Van Dijk, W. W., Ouwerker, J. W., Smith, R. H., \& Cikara, M. (20I5). The role of selfevaluation and envy in schadenfreude. European Review of Social Psychology, 26(I), 247-282. https://doi.org/10.1080/10463283.2015.1 I II600

Van Dijk, W. W., van Koingsbruggen, G. M., Ouwerker, J. W., \& Wasseling, Y. M. (20II). Self-esteem, self-affirmation, and schadenfreude. Emotion, II(6), I445-I449. https://doi.org//0.1037/a002633 |

Van Yperen, N. W. (2006). A novel approach to assessing achievement goals in the context of the $2 \times 2$ framework: Identifying distinct profiles of individuals with different dominant achievement goal. Personality and Social Psychology Bulletin, 32(I I), I432|445. https://doi.org//0.1 I77/0|46167206292093

Vecchio, R. P. (1995). Starting out and setting up. Journal of Management, 2I(5), 833-834. https://doi.org// 0.1 I 77\%2F01492063950210050 I

Watanabe, H. (2019). Sharing schadenfreude and late adolescents' self-esteem: Does sharing schadenfreude of a deserved misfortune enhance self-esteem? International Journal of Adolescent and Youth, 24(4), 438-446. https://doi.org/10.1080/02673843.2018.1554 